\title{
Retrieving the Administrative State: Formalism, Expertise and Democracy in a Time of Crisis
}

\author{
Katharine V. Jackson, J.D., Ph.D. \\ DeOlazarra Fellow \\ University of Virginia Department of Politics
}

When accepting his Party's nomination, Democratic Presidential Candidate Joseph Biden attempted a call to arms. Americans - and indeed the entire world - face no less than four urgent crises: an ongoing pandemic; racial injustice and its consequence civil unrest; an economic depression not seen since 1929; and the increasing threat of climate change. As demonstrated by the Trump Administration's unquestionable failures, citizens must rely on their state to tackle these burning perils. Yet critics both left and right would tear down the its institutional capacity to do so. Some denounce the exercise of administrative power and discretion as illiberal, unconstitutional and obnoxious to the rule of law. Others impugn it as undemocratic, paternalistic, and corrupt. Yet without some kind of agent to carry out collective solutions to their collective problems, these perils may very well proceed unabated.

Pushing an anti-administravist agenda, (Metzger, 2016) libertarians argue that regulatory agencies are an unconstitutional fourth branch of government whose "administrative absolutism" violates the separation of powers and therefore defies the principle of limited government. (Hamburger, 2014; Kessler, 2016; cf. Ackerman, 1998) They further argue that agencies' particularized responses to complex social and economic phenomena offend the liberal commitment to universalism and the rule of law. Accordingly, they would punt agencies' responsibility for social, economic, and environmental problems either to undemocratic, inexpert courts and inefficient legislatures seemingly captured by monied interest groups (H.R. 5, Regulatory Accountability Act of 2017). Thus, environmental and economic regulation would be 
placed at the mercy of a judiciary who increasingly "weaponizes" the First Amendment in favor of big business (Purdy, 2018) - or of a Congress whose decision-making is crippled by hyperpolarization and distorted by inegalitarian political processes. (Strauss, 2020)

Conservatives with a more authoritarian inflection seek to rescue administration from its ostensible constitutional exile and illegitimate, undemocratic policymaking by subsuming it under executive prerogative. (Metzger, 2017; Strauss, 2020) If it were no longer an autonomous "fourth" branch of government, these critics argue that administration would regain democratic legitimacy by bootstrapping onto the President's electoral accountability. Yet ridding agencies of their independence by placing them at the discretion of the President gives the President control over agency policymaking without Congressional input. It thus solves a separation-of-powers problem by introducing a new one. (Waldo, 2006, p. 145; cf. Vermuele, 2016) ${ }^{1}$ More ominously, empowering the executive while legitimating it with a patina of democratic legitimacy emits a strong whiff of Schmittian politics. (Moyn, 2020; Posner \& Vermuele, 2011; Chappel, 2020) ${ }^{2}$ The prospect of a largely unbound executive claiming a popular mandate should alarm any that follow the Trump Administration's treatment of refugees, civil protestors, polluters, and political cronies.

Agency power fares little better in the hands of radical, participatory democrats. They blame administrative technocracy for a variety of social and political ailments: the reification of social differences and the juridification of human nature (Habermas, 1971); corruption and regulatory capture (Lowi, 1969); the depoliticization of economic issues and the subsidization of globalized financial capitalism (Streeck, 2017; Azmanova, 2013); and, ultimately, the constellation of populist politics currently threatening liberal democratic states. (Arato, 2017)

\footnotetext{
${ }^{1}$ Arguing that no such problem exists as Congress willingly delegated such policy-making to the executive.

${ }^{2}$ Further, as Madison notes in Federalist 51, it would give perhaps give too much unchecked power. "[A] power independent of the society may as well espouse the unjust views of the major, as the rightful interests of the minor party, and may possibly be turned against both parties."
} 
Their solution, unlike the libertarians, is democratization of agency decision-making. (Rahman, 2018; Emerson, 2019) While their suggestions are welcome, such a simple answer may deprive agencies of the nimble expertise necessary to address environmental and economic crises. Further, they not only risk reproducing within agency regulation and adjudication the very social, economic and political inequalities they were meant to redress (Lowi, 1969). They also risk devolving decision-making into units too small, too cumbersome, or too inexpert to effectively implement the law. Finally, democratization may just displace the false consensus of technocratic experts onto a nonexistent popular consensus regarding matters of economic, environmental and racial justice.

In this paper, I contend that this multi-pronged anti-administravist attack against agency discretion relies upon an overly formal conception of constitutionalism that too neatly divides the state's duty to (1) protect rights and limit government power and (2) provide the procedures necessary for democratic will-formation. It is a conception that takes too literally the concept of popular sovereignty and relies on a moral order external to the political system itself. It also fails to address the technical know-how and instrumentalism necessary not just to give effect to democratic decision-making, but also to form a democratic will to begin with.

Rather than critiquing agencies for violating the separation of powers, for their overreliance on undemocratic technocrats, or for their indifference to universalizable legal principles, I argue that administration does indeed carry constitutional credentials and that the insights gained from political theory's "representative turn" (Urbinati \& Warren, 2008) can enhance them. By understanding agencies as embedded in a larger system of public reason, representation, lawmaking, democratic accountability and law enforcement, political theorists can begin to assess the legitimacy of government agencies without any "idolatrous" (Vermuele, 2016) commitment to legal and procedural formalism - a formalism that fails to historicize and capture the values 
underlying our commitment to the separation of powers (Vile, 1967). I suggest that agency institutions should be measured against the fundamental principle of equal human worth and the notion that popular sovereignty demands not consensus and consent, but instead institutions that permit citizens to understand themselves as co-equal authors of the laws that bind them. I argue that we should tailor agencies' procedures and powers in a way that: (1) allows citizens an equal chance to make demands upon agency action; (2) accounts for society's very unequal playing field; and (3) permits them to act as the purposive collective agents that can capably implement democratic lawmaking. To illustrate, an agency tasked by Congress to regulate monopoly might eschew some forms of democratic input if that input weakens its capacity as a corporate counterpower. (See NLRB v. Jones \& Laughlin Steel Corp., 301 U.S. 1 (1937); Clegg, 1951)

This paper will proceed as follows. Part I will situate administrative agencies in an understanding of liberal, democratic constitutionalism that eschews outmoded notions of popular sovereignty and natural law. It then makes a positive case for agency authority by drawing from some of the insights gained from political theory's "representative turn," modified to account for agencies' explicitly instrumentalist function in collective decision-making. Finally, Part I concludes by making some suggestions to improve the legitimacy of agency action.

Part II addresses some common objections to administrative power: that it violates the separation of powers and the rule of law; that it relies too much on undemocratic expertise, technocracy and false consensus.

\section{Part I: The Case for Administration}

Democracy guarantees rule of "we the people." Democratic citizens, possessing inalienable rights, are to come together, deliberate, and jointly create the laws that bind them. So it comes as no surprise that many think of the administrative agency, with its unaccountable expert 
technocrats, policymaking autonomy, and immunity from invasive judicial review, as an institution antithetical to liberal constitutional democracy.

Yet intuitively, these knee-jerk objections cannot be quite correct. Agencies do carry some obviously democratic credentials. As Vermuele (2016) points out, they themselves are the creation of Congressional lawmaking. Bruce Ackerman (1998), in his seminal work, even argues that agencies carry Constitutional credentials. They were birthed through multiple hyperpolitical elections and survived multiple Constitutional challenges within the Courts, the Executive, and Congress.

Further, if democratic lawmaking is to mean anything, there must be some kind of agent or instrumentality to carry it out. (Wilson, 1887) A Congressional decision to levy a tax is meaningless without an Internal Revenue Service to collect it. Moreover, it should come as no surprise that the execution of Congressional decision-making will inevitably involve some policy decisions. First, as Dewey pointed out long ago, will is not so easily separated from its follow through. We often update our ends to reconcile them with the available means. And we will select amongst available means with our multiple and often conflicting ends in mind. Purposive-rational and communicative action cannot, pace Habermas (1971), be so neatly divided. Administrative agents, like individual agents, will inevitably face the same kind of decisions. (Richardson, 2003; Dahl, 1947, p. 3). Second, lawmaking is, by its nature, always more abstract than we would like. (Hayek, 1976, p. 11; Shklar, 1986) There will always need to be elaboration and application for particular circumstances. As Justice Holmes, Jr. noted in his influential Lochner v. New York dissent, "general propositions do not decide concrete cases." (198 U.S. 45, 76 (1905)) Thus, we are usually comfortable with the fact that courts do more than just "call balls and strikes." (Strauss, 2020) Agencies likewise tasked to implement and enforce laws will inevitably do the same. The 
question, rather, is how we should handle these "agency costs" - not whether we can get rid of them completely.

Nor can it be true that any agency policymaking lacks any Constitutional tether. From their very inception, agencies struggled internally to accommodate their actions to Constitutional requirements. (Metzger, 2013) Though often light-touched, federal courts continue to review their actions for their Constitutional credentials. The Administrative Procedure Act confines their adjudication and rulemaking by imposing principles of due process and requiring public input.

\section{A. Democratic Sovereignty and Citizens' Rights}

This section will elaborate on these intuitions. Namely, many objections to agency power presume antiquated conceptions of sovereignty and rights. They juxtapose a powerful organ-body

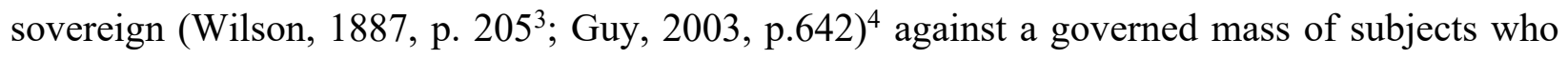
hold an array of pre-political rights that require protection. Many critics posit the state as an agent or 'body' claiming what Jean Bodin set forth in the sixteenth century: supreme, absolute, and indivisible power to make law. (Bodin, 1576, p. 122) This all-powerful body is thought to be represented by the U.S. Congress (Posner \& Vermuele, 2011) ${ }^{5}$ as the agent of the popular sovereign. To preserve citizens' natural liberties, this representative of the popular sovereign is constrained by a separation of powers, checks and balances, a Bill of Rights, etc. - each policed by independent Courts capable of identifying and enforcing citizens' inalienable rights. (Posner \& Vermuele, 2011) ${ }^{6}$ If this is indeed the rubric of the liberal democratic constitutional state, it is difficult to find where agencies may comfortably fit. They are not Congress - and so their

\footnotetext{
${ }^{3}$ Juxtaposing democracy's "corporate, popular will" against the will of an autocrat like Napoleon and Friedrich III of Prussia. Later, Wilson calls it "public opinion," which "must rule" in a democracy.

${ }^{4}$ Administration and lawmaking is parsed by early $20^{\text {th }}$ century reforms as "the expression of the state will" and "the execution of the state will."

${ }^{5}$ Calling this the idea of "legislative primacy."

${ }^{6}$ Calling this the idea of "liberal legalism." See also Shklar, 1986.
} 
policymaking cannot be legitimate expressions of the popular will. They are not subject to robust judicial review, and so they might violate natural liberties with impunity. Fortunately, this rubric is wrong.

\section{i. Democratic Sovereignty}

True, for much of modern Western history, sovereignty, understood as the right to rule, was thought to be held by a specific body: either the person of the monarch or a particular body of legislators. Hobbes, for example, imagined a state of nature full of individual human beings forming a covenant to authorize and relinquish their natural liberties to a "Mortall God," i.e., the modern state, represented (or re-presented) in the human bodies of the King or legislature. Jean Bodin, to take another familiar example, understood sovereignty to rest with the King. This body (understood collectively or in the singular) would rule over subjects, another separate ontological phenomenon. After the democratic revolutions, some theorists analytically merged this two-part ontology. Communitarians (Habermas' term) imagined "the people" not only replacing the king or king-in-parliament as sovereign, but also governing itself as a subject. They thereby attempted to create an identity between ruler and ruled. Rousseau's volonté générale serves as a model for this kind of thinking. It is a sovereign-subject hat trick: the ruled become the ruler, the democratic "people," understood as a body, a "unitary macro-subject," (Kalyvas, 2005) come to possess what was once the body of the king. Carl Schmitt likewise attempted to endorse this identity between governed and governor, although with some alarming, homogenizing implications. (Schmitt, 1988; see also Arendt, 2006, p. 60) Populists in the $19^{\text {th }}$ century challenged political leadership precisely because it betrayed the will of the sovereign people. (Canovan, 2005, p. 75) Indeed, some even 
understand constitutionalism and liberal rights as illegitimate constraints on the people's sovereign power. (E.g., Novak, 2002, p. 253) ${ }^{7}$

Of course, there are flaws in this equation. The "people" cannot rule. (Lefort, 1988) The entire population of a diverse community of hundreds of millions cannot be present within governing institutions. Nor would that population likely ever find a unanimous general will, no matter how constrained and qualified their public reasoning. As a result, the old gap between ruler and ruled remains, even if the offices of rule might be staffed by democratically elected representatives or shifting democratic majorities, and even as actual power was split within constitutional systems, legal authority limited, divided, and separated into distinct offices. (Morgan, 1989, p. 53) In other words, the merger between ruler and ruled attempted by the democratic revolutions did not remove the danger of heteronomy. (Grimm, 105, p. 31; Canovan, 2006, p. 29). Some (body) would wield public power, and the rest would be subject to its rules.

As a result, it can be no objection to agency policymaking that it usurps power from the popular sovereign. Because so, too, do the elected representatives who likewise cannot logically or credibly speak with the voice of the "sovereign people." The trick, as Lefort (1986) notes, is ensuring that the place of power remains an empty one, where no body at all is ever permitted to rule permanently.

Lawmaking under constitutional liberal democracy is thus a question of developing transparent and accessible collective decision-making procedures that ensure that all citizens can understand themselves as co-equal authors of the laws that bind them. (Cohen, 2017, p. 569; Grimm, 2015, pp. 37, 73-4; Benhabib, 2009, p. 693; Webber, 2009, pp. 19-20; Habermas, 1996)

\footnotetext{
${ }^{7}$ Addressing early $20^{\text {th }}$ century critiques of obstructive laissez-faire legal systems.

${ }^{8}$ The "democratic sovereigntiste" argument means "that there be clear and recognized public procedures for how laws are formulated, in whose name they are enacted, and how far their authority extends."
} 
Although contemporary notions of constitutional liberal democracy ascribe the highest legitimate source of authority to "the people," (Cohen, 2015) they do not understand "the people" as a reified, homogenous whole. Instead, it is a motivating principle of behavior and a critical normative standard meant to ensure that lawmaking occurs under conditions such that all can understand themselves as its joint authors. (Morgan, 1989; Habermas, 1996; Rosanvallon, 2011) It orients public reason, calling on citizens to exercise their political liberties not in their individual selfinterest alone, but in terms of human equality and the public good. It demands that political institutions remain accountable and responsive to popular complaints. It unlocks the doors of power and forces the inclusion of voices previously ignored. It is a principle of justification and critique, not a proper noun.

Of course, contemporary notions of sovereignty acknowledge that there will always be a "gap" between government officials and legal subjects, and so acknowledge the possibility of heteronomy. (Lefort, 1988) But this gap is not something to be eliminated. Doing so would force homogeneity upon plural, differentiated and continuously changing societies. Rather, we might understand the gap as productive of individual liberty, or as a constitutive tension. It encourages democratic citizens and institutions to remain attentive to claims for inclusion and responsiveness. It reminds them that no person, group or indeed any body of people can claim sovereignty and so inspires governmental restraint and respect for difference. And it recalls to us the notion that all are regulated under the Constitution -- even those in charge. (Cohen, 2017, p. 568)

It is at least possible that administrative agencies can be made consistent with the requirements of constitutional popular sovereignty. Namely, the question is whether and to what extent they operate according to procedures that allow citizens to understand themselves as coequal authors of those policies. Their rulemaking can, and indeed already does, incorporate input 
from everyday citizens - though certainly the "notice and comment" provisions of the Administrative Procedure Act can and should do much better. Citizens can contest agency action when they elect Congressional Representatives with the power to undo or modify it through legislation. So, too, when they elect Presidents with the power to issue increasingly influential executive orders.

\section{ii. Individual Rights and Liberties.}

Nor can there be an objection to agency policymaking based upon its skirting of judicial review. Judicial review does not expertly protect and apply an array of identifiable pre-political liberties held by a pouvoir constituent against a potentially tyrannical pouvoir constitué. (Waldron, 1999, p. 247) It is instead but one part of a constitutional procedure meant to allow human beings, each carrying equal moral worth, to jointly create the rights they give themselves. Courts provide, at best, an interim solution to ongoing rights conflicts. There is thus room for agencies to play a role in the democratic elaboration of rights.

To be sure, rights did not always take on a constructivist meaning. In the past, the sovereign was sovereign because its power was understood to be legitimate. In turn, its legitimacy derived from some higher, outside source of authority legibus solutus. In the early modern period, Bodin argued that sovereignty, unlike tyranny, "was bound by the laws of nature prescribed by God." Thus, even if a king's sovereignty was juridically absolute and legally unaccountable, "it remained a morally subordinate power, "answerable for its conduct to the [divine] moral law." (Bourke, 2017, p. 4) (citing Bodin, 1576, p. 211; see also Morgan, 1989, ch. 1; Canovan, 2005, ch. 2) Later political actors claimed as their source of legitimate authority an imaginary "people," or, in Richard Tuck's colorful vocabulary, "the sleeping sovereign," who possessed inalienable, natural rights superordinate to the state. (See also Canovan 2005, ch. 2; Shklar, 1986) They would then demand 
that the sovereign power respect these rights or else face legitimate rebellion. (Grimm, 2015, p. 30; Canovan, 2005, p. 17; Locke's Second Treatise) Regardless of the changing sources of legitimacy - God, 'God-given natural rights,' or liberties derived from a priori reason - whether the sovereign power could claim legitimate rule would depend upon how well it fulfilled these objective criteria. (Dahl, 1985, p. 24) Government action, including the Constitution itself, was judged according to how well it aligned with pre-political notions of justice, natural rights, or, indeed, religious moral authority. (Schragger \& Schwartzman, 2016, p. 353)

When critics of the Administrative State attack it for its immunity to judicial review and "rule of law," it is usually this pre-political understanding of rights on which they rely. Rights, being discoverable things that exist "out there" somewhere, can be identified and applied in a straightforward way by unelected specialists - the very way that, as Chief Justice John Roberts put it during his Senate nomination hearings, baseball umpires "call balls and strikes." (Winkler, 2018, p. 356)

Yet as Weber diagnosed, the great problem of secular, rationalized modernity is our lack of confidence in any outsourced moral authority. Contemporary liberalism admits the fact that there can be no consensus regarding notions of moral truth. It therefore quarantines the question, holding instead that the only legitimacy a governing authority can claim derives from an empirical, Rawlsian 'overlapping consensus' regarding the norms according to which diverse people can arrange their collective life peaceably together. (Waldron, 1999, pp. 244-45) No longer can we reach to superordinate natural law theories, even those incorporated into social contract models, for instruction. (Grimm, 2015, p. 30)

Instead, the construction of rights depends upon a fair decision-making process that attempts to cash out the promise of equal human worth - while always remaining subject to critique 
along the same terms. ${ }^{9}$ They begin as abstract concepts, ${ }^{10}$ (Webber, 2009; Benhabib, 2006) and, in their most abstract form, they are a "right to have equal rights." They are articulated and elaborated by individuals within discrete, historical democratic polities whose institutions are, hopefully, oriented towards cashing out the promise of the equal liberty as they themselves understand it. (Habermas, 1996) Rights are the result of social movements that emerge within civil society and, after democratic discourse and procedure, are codified within the law through both Constitutional and extra-Constitutional procedures. (Cohen \& Arato, 1994; Ackerman, 1998)

And when citizens cannot agree on the meaning of the rights they give themselves, they should resolve their conflict not by giving the final word to the often partisan occupants of the Supreme Court bench, but in the only way that respects them as co-equal authors carrying equal moral worth: through a fair vote. (Waldron, 1999, p. 248) People, after all, "disagree about what rights we have or ought to have," and so "the specification of our legal rights has to be accomplished through some political process." (Waldron, 1999, p. 243) Democracy is, according to Waldron, the process that we should use to settle disagreements about the scope and meaning of rights because we, as rights-bearers, demand an equal voice when it is our rights that are at stake. (Waldron, 1999, pp. 247, 250)

Perhaps more important, the content of rights must remain always contingent, contestable, and open-ended. (Urbinati, 2014) Whatever resolution may temporarily arrive in Congress or the Courts, uncertainty about both future factual circumstances and normative commitments precludes any final answer. It leaves the questions of rights always within the grasp of democratic citizens.

\footnotetext{
${ }^{9}$ Laborde (2017) notes that this understanding of legitimacy does, at the end of the day, rest on an important assumption: that human beings prioritize political justice before they value living a life according to their ethical beliefs.

${ }^{10}$ Democratic discourse invariably contains lingering meta-ideals of equality and liberty, justified using reason (whether analytical or through discourse) and ideas of "the common good." In other words, liberal constitutional democracy does rely on an abstract a priori concept of equal moral worth.
} 
(Webber, 2009, pp. 7, 38) The abstract rights that democratic practice concretizes are not indefeasible principles so much as "modes of problemati[z]ation" calling for democratic negotiation and discourse. (Tully, 2002, p. 207) This uncertainty is no bad thing. The perennial openness of the question of rights preserves democratic practice. For to settle on the truth about their content would mean relinquishing political sovereignty into the hands of something else entirely - namely, someone who claims a special expertise and authority about the correct interpretation of rights. Our permanent disagreement over rights motors our democracy.

Indeed, American citizens have demonstrated the co-originality of rights and democracy by politicizing and modifying their liberties throughout their history. For example, citizens politicized privacy rights, or their collective normative commitments to non-interference, when they found that their personal "private" experiences failed to align with the Constitutional promise of equal liberty. Despite the family's historical categorization as "private," women sought more equitable family laws that respected their property rights, protected them from domestic violence, and recognized their unpaid labor. (Cohen, 2004) Moreover, the "natural" economic rights protecting laissez-faire economic freedoms crumbled in the face of democratic pressure in the late 1920s. ${ }^{11}$ (See, e.g., Tooze, 2018; Negri, 1988, p. 7; Fraser, 2015; Eisner, 2011) Especially apparent during Lochner-era ${ }^{12}$ ascriptions of corporate legal rights (Pound, 1909, pp. 457-64), theories of natural property rights, couched as "vested" or "unenumerated" rights (Bloomer v. McQuewan (1852); ${ }^{13}$ Winkler, 2018, p. 159; Novak, 2002, p. 255; Dahl, 1985, p. 63) protecting Lockean "fruits of labor, ${ }^{14}$ subtended judicial awards of Fourth, Fifth and Fourteenth Amendment protections to

\footnotetext{
${ }^{11}$ Roy also explains that the 'privatization' of the corporation was itself a response to crisis - when public/private partnerships of the early $19^{\text {th }}$ century failed after the 1837 depression. (Roy 1997, 72)

${ }^{12}$ Lochner v. New York, 198 US 45 (1905).

${ }^{13} 55$ U.S. (14 How.) 539, 553.

${ }^{14}$ Justice Stephen Field (dissenting) in Slaughterhouse Cases, 83 U.S. 36, 90 (1873).
} 
corporations. (Dahl, 1985, pp. 72-73) But American Progressives successfully challenged laissezfaire and its jealous defense of the market. (See Eisner, 2011, p. 34) ${ }^{15}$ In 1909, jurist Roscoe Pound offered a devastating critique of freedom of contract. He argued that courts, when deciding economic disputes, should not rely on ossified legal formalism to vindicate liberty. Instead, they should look to the consequences of applying legal doctrine to human lives, modifying it when necessary to cash out its commitment to equal liberty. ${ }^{16}$ In 1926, John Maynard Keynes (1963, pp. 313-14) $)^{17}$ jettisoned the idea of a natural private ordering that deserved robust rights-based protections. In his essay "The End of Laissez-Faire," Keynes made a convincing case for state intervention in the interest of human welfare - a case that, for decades, seemed to win the day. Yet by President Roosevelt's 1944 State of the Union Address, a second bill of social rights provided justification for an expanded social welfare state. A decade later, Polanyi (2001) was able to offer an empirical theory about a "double movement" that leads to social democracy.

Thus, agencies cannot be dismissed as illegitimate for the "Chevron deference" afforded to them by Courts who are forsaking their duty to expertly police Americans' formal rights and liberties. Courts hold no monopoly on the interpretation of rights. It is at least possible that when the EEOC elaborates on the meaning of the $14^{\text {th }}$ Amendment, as articulated by Congressional civil rights statutes, it is taking part in a systemic process of democratic rights-construction that does,

\footnotetext{
${ }^{15}$ Citing, inter alia, the creation of the Federal Reserve Bank in 1913 and Federal anti-trust regulation.

${ }^{16}$ Pound explains the tendency to cling to ideas of natural rights as against the state by, among other things, "the sharp line between law and fact in our legal system which requires constitutionality, as a legal question, to be tried by artificial criteria of general application and prevents effective judicial investigation or consideration of the situations of fact behind or bearing upon the statutes." (Ibid., p. 458) In other words, the normative barrier between what is protected by law and is regulated by law ought to be permeable, based upon consequences those laws bear for individual freedom.

${ }^{17}$ Interestingly, Keynes in this essay proposes, as an alternative to laissez-faire, a form of economic corporatism of "Universities, the Bank of England, the Port of London Authority, even perhaps the Railway Companies" whose "[A]ffairs are mainly autonomous within their prescribed limitations, but are subject in the last resort to the sovereignty of the democracy expressed through Parliament." (Ibid., 314)
} 
indeed, permit each and every citizen to understand themselves as co-equal authors of the rights that bind them.

\section{B. Agencies and the Representative Turn}

With a better understanding of popular sovereignty and rights within constitutional liberal democracy, critics of the administrative state cannot rely on agencies' lack of Congressional oversight and immunity from judicial review to undermine their legitimacy. Instead, it is at least possible that they can be made compatible with the foundational commitment to human worth if they operate according to procedures that permit citizens to understand themselves as co-equal authors of the laws that bind them. (Urbinati \& Warren, 2008, p. 395) Yet what might those procedures look like? Here, some insight from political theory's representative turn may prove fruitful.

i. Defining the Turn

The representative turn within political theory pushed back against the idea that representative democracy is merely a watered-down version of democracy, a pragmatic and elitist alternative when the demos is too large and cumbersome for more direct institutions. For a long time, democratic theorists like Rousseau, Schumpeter and Sartori held that the election of representatives is a very-much second-best way of ascertaining the will of "the people," adopted only because it is impossible (both practically and perhaps normatively) to incorporate each and every citizen into the lawmaking enterprise. Rather than direct, deliberative, participatory democracy of the ancients, we moderns must settle for a principle-agent model and a political division of labor that will inevitably involve some kind of aristocracy. (Manin, 1997)

In contrast, the new theories of representation hold that representation is no mediocre substitute, but instead "an intrinsically modern way of intertwining participation, political 
judgment, and the constitution of demoi capable of self rule." (Urbinati \& Warren, 2008, p. 402) Eschewing any outmoded conception of organ-body sovereignty, they judge representation according to how well it allows morally equal human beings to affect, in equal measure, the laws that bind them - a fundamental norm that Urbinati and Warren call "democratic autonomy." (Ibid., 395)

Most fundamentally, they encourage democratic theorists to conceptually separate the norms that democracy should instantiate from the institutions designed to bring them to life. By refusing to reduce democracy to any particular kind of collective decision-making procedure, they permit the assessment of political institutions of all shapes as sizes according to this single standard. (Ibid.) As Stephen Holmes puts it, representation is part and parcel of the constitutional decision-making procedures that, "rather than restricting a preexisting will [of the sovereign 'people']...actually creates a framework in which the nation can for the first time have a will." (Holmes, 1995, p. 164) It is part of the procedures and mechanisms of collective action, rules of the game, that facilitate and enable normative ordering and decision-making. (Waldron, 1999, p. 277)

In particular, theorists of the representative turn observe that elections, rather than hamhandedly taking stock of democratic opinion or "the sovereign will," help structure and constitute political debate. They set agendas for discussion, motivate organizing by providing discrete targets and timelines, institutionalize opposition and "countervailing discourses" (Dryzek \& Niemeyer, 2008), and encourage citizens to exercise judgment over matters of public concern. They frame continuous processes of bottom-up demands from citizens and top-down reactions from representatives. They challenge voters to think publicly and into the future. As a result, they "activate" citizens well beyond the formal act of casting a ballot while preventing public discourse 
from disintegrating into a cacophony of interventions that remain unchanneled towards any common goal. (Urbinati \& Warren, 2008, pp. 391-92; Habermas, 1996) They thus also enjoy an "elective affinity" with deliberative democracy, since they facilitate ongoing and effective public discussion, critique, and consensus-formation. (Urbinati \& Warren, 2008, p. 402) (citing Rosanvallon, 2006; Manin, 1997) Precisely because the represented are not identical to the representative, representation provides a constitutive tension that, counterintuitively, actually mobilizes democratic discourse. As a very recent example, the 2020 U.S. Presidential Election spurred public debate and mobilization surrounding rights to health care, climate change, and racial justice. Candidates responded with proposed policies while citizens reacted and mobilized in an ongoing process of collective decision-making - all motivated by a November deadline.

\section{ii. The Turn's Applicability to Administration}

Those who attack agencies as illegitimate lawmakers levy the same kinds of claims that Rousseau levied against democratic representation. For Rousseau, the sovereign general will could not be represented, but must rise directly from the people themselves. Representation, therefore, should be confined to a strict principal-agent representation, a fiduciary contract whereby the agent is stripped of any policy-making discretion whatsoever. Government is to blindly obey the political orders from the sovereign. Similarly, many anti-administrativists understand agencies as the fiduciaries of Congress - itself a fiduciary of the people - and so should, "like a machine without a mind," (Brugue \& Gellego, 2003, p. 426; see also Turner, 2003, p. 14) avoid playing any role in the formation of law and policy. (Posner \& Vermuele, 2011; Smithburg, 1951 ${ }^{18}$ ) For if

\footnotetext{
18 'If only a few top positions are considered to be 'policy-making' it logically follows that lower positions can be filled on the basis of nonpolitical or 'merit' examinations since the occupants of these positions will be merely the servants carrying out the 'political will' as expressed by the President and the Congress." (p. 60)
} 
administration starts making its own decisions, it can only interfere with the democratic sovereign. (Brugue \& Gellego, 2003, p. 427; Richardson, 2003, p. 119 ${ }^{19}$ )

Yet if representation is not an inferior re-presentation of the will of an embodied sovereign, but instead an institutional tool that helps citizens understand themselves as co-authors of the laws that bind them, then there is little reason to exclude agencies ex ante from the lawmaking process. (Smithburg, 1951, p. 66) 20 $^{20}$ Ranvallon, in fact, argues in Democratic Legitimacy (2011) that agencies can and do serve as representative agents, albeit of the trusteeship variety, along with their elected counterparts. More recently, Blake Emerson (2019, p. 65) argues for a Progressive Hegelian view that holds that there can be an ongoing, constitutive relationship between administrative agencies and citizens. Mary E. Guy, past president of the American Society for Public Administration, characterized the people serving public agencies as "facilitators, interpreters, and mediators of public action" (2003, p. 652) - a characterization that might likewise be attributed equally to elected representatives. The interest-group politics of administrative policy-making can, like the interest-group politics of Congressional lawmaking, provide “opportunities for policy proposals to be criticized from a variety of directions, both before and after their implementation." (Dryzek \& Niemeyer, 2008, p. 482) Administration can thus, like Congress, provide a forum where "conflicts and rendered both comprehensible and solvable" and the values at stake are sufficiently "specific and understandable to generate opinions and dialogue.” (Brugue \& Gellego, 2003, p. 429)

\footnotetext{
${ }^{19}$ Arguing against "treating the government as a single macrosocial subject with its own set of values."

20 "If it were shown empirically that administrative officials were actually closer to the trends of public opinion than were the majority of Congressmen, it might be necessary to reassess the roles of the two groups....the finding would raise a number of serious questions concerning the 'principles' of organization which rest implicitly on the notion that Congressmen are much better equipped and much more willing to recognize the voice of the public than are the administrators." (p. 66) The plausibility of the idea of agencies as part and parcel of representative democracy is also illustrated by Lowi (1969), who called the agency-centric interest-group-based representative government a new, "Second Republic."
} 
Regardless, unless one holds to the unrealistic view that ends can be separated cleanly from means, that there is always a hard boundary between willing and doing, (e.g., Smithburg, 1951, p. 60; Dahl, 1947, p.3) agencies will continue to make value-laden policy decisions that require democratic legitimation. Here, I argue that the new theories of representation indicate that agencies should be judged under the same standard to which representative institutions are subject: how well they serve the norm of democratic autonomy. The implication is that agencies should be democratized, but not in a way that simply replicates electoral or participatory institutions. In this way, agencies might play an active role in legitimizing constitutional liberal democracy - rather than serve merely as a politically unimportant appendix. (See Brugue \& Gellego, 2003, p. 428)

\section{iii. Lessons}

Under the representative turn, representative systems can be judged as more or less successful according to whether and to what extent they: (1) stimulate public debate; (2) motivate bottom-up demands that are (3) followed by top-down responses; (4) encourage individual reflection and judgment on political matters; (5) include all citizens while (6) ensuring they have equal influence. We might judge administrative agencies according to the same standards.

Though they presently serve all these function to some extent, there can be no doubt that administrative agencies can do a much better job. Agency actions do stimulate public debate at least sometimes, as seen by public reactions following recent Executive Orders regarding immigration, environmental deregulation, etc. The public criticism to which they are routinely subject arguably, at least according to Vermuele and Posner (2011), limit executive agencies far more effectively than do the tenets of statutory delegation and the separation of powers. And these actions have obviously motivated bottom-up demands - but they are demands that are not often met satisfactorily with top-down responses from officials and officers. Since agencies are obligated 
to provide notice and comment under the Administrative Procedure Act when they change their regulations, they make an attempt at inclusion. Furthermore, as administrative law scholar Jon D. Michaels (2017) points out, agencies, for a large part, mirror the collective decision-making processes found within normal lawmaking. And so citizens can practice politics in a manner similar to those surrounding elections. According to Michaels, agencies' political appointees play the role of the elected executive, apological civil servants provide a judiciary, and civil society organizations often function like the legislature. (Ibid., 52)

But too often this inclusion is rarely determinative and heavily influenced by inequalities in wealth and experience. (Emerson, 2019; Rahman, 2016) Moreover, when influence is enjoyed equally, it is the exception rather than the rule. (Lowi, 1969; Holyoke, 2015) Given lobbyists' outsized role in rulemaking, attenuated Congressional oversight (Emerson, 2019, ch. 4), and the self-appointment of interest group leaders, (Holyoke, 2015, p. 223) it is at best unclear whether citizens enjoy equal opportunity to impact agency policymaking directly through the agency or indirectly through electoral politics. Yet inoculating agencies from interest group pressure by granting them political independence, as suggested by some Legal Realists and Progressives in the early $20^{\text {th }}$ century, (Ernst, 2014; Fishkin \& Forbath, 2014) may simply substitute one undemocratic disease for another. Further, since agencies deal with complex phenomena and technical matters, they should likely update and improve their transparency to facilitate public deliberation and inclusion. Indeed, agencies might even take steps to actively solicit and incorporate citizens' views.

The task need not only be amelioratory, bringing agencies themselves better in line with constitutional liberal democracy's fundamental moral commitments. Agencies can themselves serve as institutions that enhance equal human worth within the entire constitutional system. They 
provide additional points of entry for citizens otherwise marginalized from public decisionmaking. (Rahman, 2016; Carillo, 2020) For example, minority communities often excluded from electoral politics might more fruitfully engage with administrators tasked with implementing social welfare rights. If agencies render their input determinative rather than merely advisory, they might even enhance democratic autonomy beyond that provided by electoral politics. (Brugue \& Gellego, 2003, p. 430) And agencies can provide the information necessary for citizens seeking to exercise judgment on many matters of public concern. One need only consider the usefulness to democratic deliberation that the $\mathrm{CDC}$ might perform during a pandemic.

Stimulating public debate, and encouraging bottom-up demands and top-down responses, might be better served, moreover, if agency procedures are reformed according to Wilson's advice: to find "the simplest arrangements by which responsibility can be unmistakably fixed upon officials; the best of way of dividing authority without hampering it, and responsibility without obscuring it." (1887, p. 213). After call, "vigilance could be aided by the unmistakable placing of responsibility." (Ibid.) Too often, government responsibilities overlap and blend; multiple agencies target the same things. Though such complexity empties the place of power, it obscures this power so much that democratic feedback may become impossible. In addition to more clearly identifying responsible personnel, agencies might make more explicit the end-values that they purport to serve. (Dahl, 1947, p. 4) By giving citizens a clear target for their demands, and by giving civil servants a motivation to respond to those demands, agency policymaking and implementation would better reflect democratic autonomy.

\section{Agencies and Agency}

Although the lessons of the Representative Turn are powerful, they cannot be adopted without modification. Unlike elected political representatives, agencies do not just make policy. 
They are also meant to implement it. They are "government in action," (Wilson, 1887, p. 198) the "instruments of collective action." (Guy, 2003, p. 652) They do not only serve the process of creating the collective will; they are also the political instruments intended to exercise it. Administrators both interpret the public purposes set forth to them by Congress and carry them out. (Emerson, 2019, p. 9; Waldo, 2006)

This characteristic creates at least two important criteria that the institutional design of administration must accommodate. First, when they elaborate on their policy goals, they should not provide an opportunity to relitigate de novo the hard compromises and agreements already settled by Congress in regular lawmaking. Law thus constrains the scope of intra-agency decisionmaking. It also implies that their decision-making should not always remain wide open to democratic feedback. Second, agencies, as instrumental agents, will be constrained in their decision-making not only by their ends, but also by the feasibility and necessity of the means available to pursue them. Instrumental reasoning will likewise curtail the scope of democratic deliberation. Moreover, agencies serve a crucial fact-gathering function for democratic publics. It is often from agency research and expertise that citizens find the ground upon which to stand (Arendt, 1967; Verovsek, 2020) as they engage in collective decision-making. If these facts are to serve their purpose, they cannot be subject to freewheeling democratic debate. Nevertheless, one must be careful not to take these constraints too literally. Often, there is significant scope for political deliberation despite them.

i. Relitigating Policy Debates

Though delegation statutes are by their nature too general to be applied without agency elaboration, agencies ought to avoid becoming the primary location of democratic contestation of those statutes. As it is currently practiced, American democracy directs its citizens to traditional 
electoral politics to resolve pressing social conflicts and problems. Indeed, Americans have had a long education in using the procedures contained in Congressional and Presidential elections to situate their discourse and judgment regarding their collective ends. Adding a new decisionmaking venue to the mix may confuse debate, divide energies, and distract. (Lowi, 1969) Furthermore, federal statutes provide both a starting point and ending point for public debate, providing a solid target around which discourse might be mobilized. Perhaps more importantly, citizens interested in agency policymaking are usually comprised of a specific subset of the voting population. (Brugue \& Gellego, 2003, p. 445) As a result, any major policy changes made exclusively within the ambit of agency politics will deprive many of their ability to understand themselves as co-equal authors of the laws that bind them. Unless agencies are opened to universal feedback through some kind of regular national franchise, relitigation may threaten political equality. For only in elections do citizens enjoy an opportunity to resolve conflict in the only way that respects them as moral equals: a vote. (Waldron, 1999)

Historically, interested parties - usually enjoying an unequal share of wealth and resources - have used agencies to undo democratic lawmaking that they find repugnant. For example, lobbyists associated with investment banks and their law firms swarmed the Securities and Exchange Commission following the 2010 Dodd-Frank financial regulation. (Beckel, 2011) If left untethered to the precedents set by Congress, agencies will consequently afford some citizens the opportunity to undermine political equality by walking back Congressional decisions that are subject to national democratic accountability mechanisms. At worst, it allows elites to capture collective decision-making processes (Holyoke, 2015) and may even lead to the privatization of public functions. (Offner, 2019) This danger proved so acute that, during the Progressive era, 
reformers argued in favor of agency independence rather than democratization. (Fishkin \& Forbath, 2014)

Of course, it is not unusual for Congress to punt contentious political issues to agencies for resolution (or the avoidance thereof). Unless those agencies include some kind of democratic decision-making procedure, what policies result may lack any democratic legitimacy whatsoever. A prime example is the Federal Reserve Act of 1913: that the central bank should manage employment levels and price stability. (Ibid., § 2A; van't Klooser, 2020) Yet, especially since the 2008 financial crisis, the Fed has been making decisions that can no longer credibly be described as merely technocratic. ${ }^{21}$ (Tucker, 2018; Jackson, 2020) It blatantly engages in distributional politics as it decides to divert public resources to some actors but not to others. (Carillo, 2020; Tankus, 2020) Opening the Fed to democratic feedback, whether through intra-agency or Congressional politics, would go some way to assure democratic autonomy.

ii. Agencies as Agents under Constraint

The scope of intra-agency democratization thus should be tightened to avoid giving actors an opportunity to amend the political choices made through regular lawmaking. It is also restricted because agencies are instrumental agents. Unlike Congress, they must do more than set the collective will. They must carry it out. Agency decision-making is thus constrained by the dictates of instrumental reason. ${ }^{22}$ Its institutions and internal procedures, accordingly, cannot remain open to all viewpoints and opinions.

\footnotetext{
${ }^{21}$ Of course, any choice between inflation (when tends to harm wealthy asset-holders and benefit debtors) and unemployment (favoring labor) has distributional consequences - and is thus political. See, e.g., Tooze, 2020.

${ }^{22}$ Richardson (2003) notes, correctly, that a significant, if not majority, of real-life political conflict is a debate over means, not ends: how to best grow the economy, lift people from poverty, reduce the national debt, decrease crime. It is a weakness of political philosophy that it does not address this phenomenon more often. Some counter-examples include Moore, 2017, Anderson, 2011, and Dunn, 1990.
} 
Although scholars accustomed to the rational reasoning of democratic political philosophy may balk, the constraints of instrumental reason can serve collective emancipatory purposes. After all, the American Constitution itself, as Stephen Holmes puts it, is "an instrument of government, not an obstacle to government; it [is] not disabling, but enabling." (Holmes, 1995, p. 153) "[A] Government intrusted with such ample powers...must also be intrusted with ample means for their execution," reasoned Chief Justice Marshall. (McCullough v. Maryland, 17 U.S. 316, 408 (1819)) Sometimes, it is only through constraint that polities can vindicate their freedom. The checks and balances, limits, and restraints imposed by the Constitution are not simply "negative devices used to prevent the abuse of power." They also "organize new practices and generate new possibilities that would not otherwise exist." (Ibid., p. 163) Constitutions "create and organize power as well as give power a certain direction." (Ibid., p. 164) In the same way, confining agency decisionmaking to matters of technique can empower democratic majorities by giving them the means to accomplish their goals. Agencies can serve democratic majorities by, as Woodrow Wilson observed in 1887, figuring out "what government can properly and successfully do, and, secondly, how it can do these proper things with the utmost possible efficiency" given the values at stake. (Wilson, 1887, p. 197) ${ }^{23}$

First, the agency's statutory purposes might preclude it from incorporating certain kinds of democratic feedback in its own elaboration of policy. For example, Congress commonly delegates decision-making and research to agency experts for reasons that might be ill-served by agency democratization. (Tucker, 2017; van't Klooster, 2020) As demonstrated so wrenchingly during the coronavirus pandemic, incorporating popular feedback on national health policy can actually undermine the democratically determined goal of maintaining public health. This is not to argue

\footnotetext{
${ }^{23}$ These values were, in Wilson's view, minimizing costs of human treasure and energy.
} 
that scientists and doctors ought to dictate national health policy in some kind of unaccountable expertocracy. Nor is it to argue that agency expertise ought to be immune from any kind of public feedback whatsoever. Certainly, experts disagree and these disagreements, often implicating questions of morality and ethics, should be resolved with democratic procedures. (Richardson, 2003; Anderson, 2011; Dahl, 1990) Agency experts might present citizens with, for example, alternative views of what is desirable and possible and thereby stimulate public debate and feedback. (Brugue \& Gellego, 2003) It is only to argue that democratic citizens should be able to rely on their agencies to provide, as far as is possible, informed and objective guidance based upon the involvement of a specially selected portion of the demos that they can then both use in their deliberations surrounding electoral politics and that carries some potential to effectuate alreadyexisting policies. (Verovsek, 2020)(citing Habermas, Bourdieu, and Foucault)

There is, consequently, a very real risk that agencies will claim legitimate authority not based upon democratic support, but upon one particularly special characteristic: expert knowledge. (Moore, 2017) "It is politically important," notes John Dunn (1990, p. 3), that the conditions of economic flourishing "are extremely difficult to understand - that they are as extravagantly complicated as they are cognitively elusive." But it is a risk that, as explained further below, might serve productive ends. And it is not one that can be avoided if democratic decision-making is to be vindicated through effective government action.

Second, citizens might task an administrative agency to pursue a goal whose achievement might otherwise be undermined if it accepted influence from a broad array of voices. For example, an agency meant to serve as a counter-power capable of breaking up monopolies or safeguarding labor rights (Galbraith, 2017; Rahman, 2016) might exclude business interests in a manner that would be unacceptable in electoral politics. To "somehow make itself master of masterful 
corporations," (Wilson, 1887, p. 201) it might recognize the material conditions of legal and social change (Kessler, 2016) and consequently avoid substantial input from the business lobby. "Bringing the state back in," to borrow Skocpol's (1985) language, might very well require that the state take on an agency distinct and independent from the interests of some of its constituents. Congress might command agencies to mobilize the nation's dispersed "producing classes" to "defeat oligarchy and to save the republic from the new aristocracy of wealth." (Fishkin \& Forbath, 2014, p. 677) President Franklin D. Roosevelt, in a 1932 campaign speech, expressed this idea in apt and colorful language:

The regulating commission, my friends, must be a Tribune of the people, putting its engineering, its accounting and its legal resources into the breach for the purpose of getting the facts and doing justice to both the consumers and investors in public utilities. This means, when that duty is properly exercised, positive and active protection of the people against private greed! ${ }^{24}$

Finally, agencies, as agents (expert or otherwise) must undertake the kind of instrumental reasoning that Weber once threatened would overtake our deliberation over our ends. They will also face feasibility constraints that challenge them to re-assess and elaborate the values that they are tasked to pursue. (Richardson, 2003) Administration does not borrow the latest ideas in private sector management science (Guy, 2003; Waldo, 2006) merely as an intellectual fashion or in ideological servitude to neoclassical notions of "efficiency." They do it because agencies, like businesses, must get things done in the real world. Both involve, in Habermas' terms, purposiverational action that "is immanently one of control." (Habermas J., 1971, p. 85) As a result, the scope of intra-agency democratization will be more limited than on might find in public reasoning

\footnotetext{
${ }^{24}$ https://www.presidency.ucsb.edu/documents/campaign-address-portland-oregon-public-utilities-and-developmenthydro-electric-power
} 
about end-values. Just as in business, technology and market constraint will constrain some choices. Hierarchy might prove more efficient than deliberation in carrying out policy proposals. Indeed, the importance of agency effectiveness, and thus the salience of technological reason, only grows once democratic publics append positive social and economic rights to a menu of negative liberties adequately policed by courts. This is why Norberto Bobbio (1987, p. 38) was able to argue that "[a]1l states which have become more democratic have simultaneously become more bureaucratic." ${ }^{25}$ And thus it is why anti-administrative attacks against ostensibly antidemocratic bureaucratization at least occasionally conceal attempts to "if not dismantle democratic power, then certainty to reduce it to within clearly circumscribed limits." (See also Wilson, 1887, pp. $200-201 ;{ }^{26}$ Dahl, 1947 , p. $3^{27}$; Ernst, 2014, p. $33^{28}$ )

While instrumental reason, expertise, and anti-democratic procedures may frustrate popular involvement, it is important to note that these constraints are not limited specifically to agency decision-making. Legislatures themselves face such limits as they set national policy. Congressional Representatives confront citizens asserting conflicting demands based variously upon science, religion, economic theory, rumor, and, indeed, conspiracy theory. (Verovsek, 2020)

\footnotetext{
${ }^{25}$ It is also more important during times of scarcity than during times of plenty. "With a new country, in which there was room and remunerative employment for everybody, with liberal principles of government and unlimited skill in practical politics, we were long exempted from the need of being anxiously careful about plans and methods of administration.” (Wilson, 1887, p. 203)

${ }^{26}$ Where government once might follow the whims of a court, it must now follow the views of a nation. And those views are steadily widening to new conceptions of state duty; so that, at the same time that the functions of government are every day becoming more complex and difficult, they are also vastly multiplying in number. Administration is everywhere putting its hands to new undertakings... Seeing every day new things which the state ought to do, the next thing is to see clearly how it ought to do them."

27 "It is difficult...to escape the conclusion that much of the debate over delegated legislation and administrative adjudication... actually arises from a concealed conflict in objectives. Those to whom economic regulation and control are anathema have with considerable consistency opposed the growth of delegated legislation and the expansion of the powers of administrative tribunals - no doubt from a conviction that previously existing economic rights and privileges are safer in the courts than in administrative tribunals..."

${ }^{28}$ On Justice Hughes: "Many social problems and conflicts are best addressed by officials who, through repeated encounters with a particular class of disputes, understood their origins."
} 
Citizens usually clash not over their final ends, but how they are best achieved. (Turner, 2003; Richardson, 2003) Political associations fail if they are unresponsive to challenges to their security and capacity. (Hirschman, 1970) Government leaders find themselves negotiating the constraints of international financial markets and capital flows. (Streeck, 2017) The answer, though, it not to give up on democracy, but to find a way for democracy to work within its constraints. ${ }^{29}$ As Dahl (1990, p. 227) notes, democracy, if it is to make intelligent choices in a complex society, "require[s] both technical understanding and sensitivity to the values involved."

\section{iii. Modifying the Lessons}

Incorporating administrative agencies within the institutions of representative democracy, as a result, does not imply the reproduction of democratic institutions within the agencies themselves. Rather, the analysis must be systemic and context sensitive. To "make public opinion efficient without suffering it to be meddlesome," (Wilson, 1887, p. 214) requires thinking through the tasks of "setting goals and executing on them," (ibid.) and whether and to what extent popular involvement will undermine not just democratic autonomy and will-formation, but also willimplementation. An agency tasked by statute to defend consumer rights in the financial system, enjoys a relatively well-identified statutory purpose. Its policymaking, therefore, likely should not emphasize the input and interests of the financial sector. Moreover, given the complexity of the financial system, it should give exhibit preference for expert opinion. On the other hand, a central bank vaguely tasked to "manage the economy" should, to protect democratic autonomy, make a greater effort to incorporate the voices of all who will be subject to its policies.

\section{Addressing Several Objections}

\footnotetext{
${ }^{29}$ Elizabeth Anderson (2011) provides an example: if citizens can make second-order assessments of expert guidance, they are not thereby deprived of democratic autonomy by such guidance.
} 
This essay argues that, in light of a better understanding of popular sovereignty and the representative turn within democratic theory, administrative agencies can fit comfortably within constitutional liberal democracies. Several objections, however, should be addressed more specifically.

\section{A. Governmentality and Paternalism}

Inspired by Foucault and the Frankfurt School, some critics of the administrative state are understandably troubled by the possibility that agencies, tasked as they are with implementation and organization, will administer human beings as objects to be managed, rather than ends to be respected. Likewise, Woodrow Wilson warned us against the unfreedom of administration: "It is better to be untrained and free than to be servile and systematic." (1887, p. 205) At least three responses can be made to such objections.

First, agencies often intervene when social life is already administered in a manner inimical to individual autonomy - just not by the government. Instead it is administered by private actors. For example, as Shoshanna Zuboff (2019) recently argues, private technological companies, through their algorithms and profit motives, control our desires and behaviors in a way that exceeds the instrumentalized dystopia imagined by Foucault. Although administrative agencies come with their own risks, they are also, perhaps, the only tool at our disposal to counteract these powerful private actors. Moreover, unlike their private counterparts, they come with some form of democratic accountability. Posing powerful government agencies against powerful private actors can achieve, if not the utopia of human autonomy, at least some degree of non-domination.

Second, Blake Emerson (2019) argues that the tension between individual autonomy, one the one hand, and paternalistic governmentality, on the other, can be a productive, constitutive one. It motivates citizens to continuously confront the limits of human will and the technological 
constraints that set those limits. It can stimulate discussion and reform: e.g., how to decentralize decision-making; how to incorporate individual viewpoints, etc. More importantly, because administrative problems might be solved by more than one technique, and because identifying the appropriate technique will require decisions about the "ethical values we apply and what we interpret statutory rules to authorize, foreclose, or require," (Ibid., p. 9) administrative decisionmaking can situate deliberation and contestation. Precisely because technique is out of the control of human volition, human beings are motivated to test it.

Indeed, especially after the 2008 financial crises and the European debt crises, many have recognized that the purportedly neutral, technocratic reasoning driving the instrumentalization of human beings often rests on debatable political values. To be sure, the social sciences, including studies of public administration, once embraced this reasoning in order to borrow some of the legitimacy granted to the physical sciences (Waldo, 2006; Guy, 2003). Now, however, their claims to scientific knowledge are more modest. The critics who push back against the notion that society can be made legible to itself are many and convincing. ${ }^{30}$ (Turner, 2003) There is thus no reason why we must continue to occlude value-laden political questions with the assurances of ostensibly neutral technocratic elites. The field of inquianry where "reason compels a unique result" (Galston, 2002, p. 69) is smaller than one might expect - and getting smaller. Stripped of the scientific veneers, administration can present less of a paternalistic threat than Foucault and the Frankfurt Scholars feared.

Finally, because agency decision-making does attend to the particular rather than the general, it presents opportunities for popular involvement that are not otherwise available.

\footnotetext{
${ }^{30}$ One notable contemporary example is the rising popularity of Modern Monetary Theory and Post-Keynesian heterodox theories of macroeconomics, both of which counter the hegemony of more orthodox monetarism of the European Central Bank.
} 
Decisions that direct and control individuals are also more susceptible to effective individual feedback - unlike general lawmaking. Agencies might therefore inspire, rather than suppress, the exercise of individual autonomy. (Carillo, 2020)

\section{B. Expertocracy}

Relatedly, critics of the administrative state warn that it inevitably leads to a technocratic, hierarchical expertocracy. To be sure, a claim to truth and knowledge is a claim to legitimacy and thus threatens an undemocratic concentration of power. ${ }^{31}$ There are, nevertheless, institutional tools available to mitigate or prevent such an outcome. Robert Dahl suggests that specialists be drawn not just from partisans and different branches of government, but also from the constituents that government means to serve and the scientific bodies from which it draws. ${ }^{32}$ Elite, expert oligarchies can be countered by competing oligarchies to prevent a concentration of expert power. (Bobbio, 1987, p. 60) Moore (2017) proposes that governments maintain ongoing opportunities for citizens to oppose, scrutinize, and protest expert conclusions. Furthermore, incorporating expert authority in democratic deliberation can involve a critical, active "reflective acceptance," rather than unthinking belief. (Ibid.) It can accommodate citizen participation, even if that participation is more limited than ordinary political judgments. (2017, pp. 72-73) As Rahman (2011) argues, there can be a way to "embed" expertise within democratic institutions and democratic reason. Administrative specialists can "engage in ethical reasoning, not as a cloistered group of enlightened experts, but rather as partners with affected persons in the elaboration of statutory norms." (Emerson, 2019, p. 64)

\footnotetext{
31 See Blythe \& Matthijs, 2018 for an application of this point to European monetary policymaking.

32 See Brown, 2009 for this last point.
} 
Regardless, the need to rely on expertise may be somewhat overblown. So too, therefore, is the threat of expertocracy. Studies in both politics and business management show that democratic feedback can serve the achievement of collective ends by improving upon the opinions of experts. (Brugue \& Gellego, 2003, p. 433) Arguably, agencies might not even be able to fulfill their policy purposes without wide-ranging democratic feedback on where problems exist and how they are encountered. (Ibid., p. 435; Mintrom, 2015, pp. 14-15) Moreover, increasing participation can facilitate policy implementation by encouraging public trust, cooperation and solidarity within what Rosanvallon (2011) called a "government of proximity." (Brugue \& Gellego, 2003, p. 436; Carillo, 2020; Waldo, 2006, p. 149 Neuse, 1983)

\section{The Separation of Powers and the Rule of Law}

While attacks from the left focus on the risk of technocratic autocracy, attacks from the right often target the exercise of agency discretion as antithetical to liberal "rule of law." They will also point to agency rulemaking and adjudication as violating the constitutional separation of powers, whereby all lawmaking is to be done by Congress and applied judicially though the Federal Court system. Further, permitting agency particularism through its rulemaking and adjudicative functions removes predictability and generality from the legal system, challenging notions of due process and inhibiting free behavior. (Ernst, 2014, p. 11)

Several responses can be made to these multifaceted attacks. First, whatever values the institutional separation of powers serve, it is to those values, and not to the form of its practical implementation, that constitutional democracy ought to devote itself. Commitment to the separation of powers as an end in itself, rather than as a means, is, as Vermuele points out, a kind of idolatry. First, the doctrine is a historical instrument, and one that changes in form as circumstances and values change. (Vile, 1967) The concept itself, according to Adam Smith, 
"seems originally to have risen from the increasing business of society, in consequence of its increasing improvement." (Smith, Bk. 1 Ch. 1) Madison, for example, admitted that it was mere "auxiliary" device, an "invention of prudence," not a final end, that could help "control the abuses of government," and that "[a] dependence on the people is, no doubt, the primary control on the government." (Federalist 51) Agencies can be designed, and have been designed, to avoid the concentration and abuse of power, although they may violate a strict and literal application of the separation of powers doctrine. Their notice and comment requirements, for example, go some way to ensure that decision-making includes "so many parts, interests, and classes of citizens, that the rights of individuals, or of the minority, will be in little danger from interested combinations of the majority." (Federalist 51; see also Ernst, 2014, p. 76 33 ) Furthermore, the separation of powers does not merely serve as a means to secure against the accumulation of arbitrary power. It is also enabling, permitting collective decision-making to benefit from specialization and "a more efficient distribution and organization of governmental functions.” (Holmes, 1995, p. 164) Administrative agencies arguably do a better job enhancing this goal than would a government hamstrung by the such a strict interpretation.

Second, the powers of government cannot be cleanly separated. Indeed, for much of modern Western history, they were not. (Vile, 1967) The judicial branch engages in both execution and legislative policymaking. "Before the rise of administration," "the courts had been the nation's de facto regulators, and they had left to juries the work of applying vague [legislative] standards." (Ernst, 2014, p. 13) Moreover, courts make policy; they do not, and cannot, merely "call balls and strikes." Abstract law, after all, does not decide concrete cases - judges do. And their application

\footnotetext{
${ }^{33}$ Noting that Justice Charles Evans Hughes would "design agencies' structure and procedures so that the affected concerns and their counsel could channel administrative discretion along reasonable lines. Courts would intervene to structure agencies' proceedings in their own image so that the affected parties could bring egregious decisions to their attention."
} 
will undoubtedly involve the consideration of values not expressly itemized in statute and caselaw.

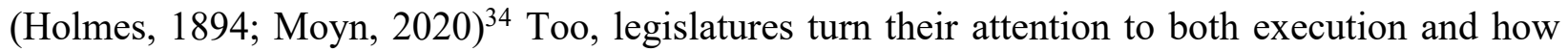
their ends might best be met. Else, the Constitution's Necessary and Proper clause would have no purpose. (McCullough v. Maryland, 17 U.S. 316 (1819)) Much of lawmaking, in addition, amounts to the adjudication of disputes amongst citizens, (Federalist 10$)^{35}$ including those disputes where some citizens believe that their rights require one thing, and others believe that they require something else. (Waldron, 1999) The laws passed by legislatures, like the opinions of courts, are often elaborations of higher, pre-existing principles. (Vile, 1967, p. 27)

The reason for this functional bleeding is conceptual, not pragmatic. Laws, reflecting legislatures' best attempts at generality and universality, are of necessity abstract. (Hayek, 1976, pp. 11-12; Vile, 1967, p. 26; Richardson, 2003, p. 119) Their application, on the other hand, will address life's particularities. And so no matter which branch issues come before, the interpretation, elaboration and application of general rules and principles will inevitably follow. "Any interpretation of law is a form of rule, and there is no way - contrary to what many of the founders believed-of disentangling 'judgment' and 'will."” (Moyn, 2020) Further, as Dewey points out, decision-making can never be neatly separated into means and ends. Ends are updated as means are considered; some ends become means for more ends. ${ }^{36}$ Any differentiation between legislative, executive, and the adjudicative reasoning, therefore, is dialogical and endogenous rather than static.

\footnotetext{
${ }^{34}$ See Pistor, 2019 for an application of this idea to property, contract and other commercial rights.

35 "With equal, nay with greater reason, a body of men are unfit to be both judges and parties at the same time; yet what are many of the most important acts of legislation, but so many judicial determinations, not indeed concerning the rights of single persons, but concerning the rights of large bodies of citizens? And what are the different classes of legislators but advocates and parties to the causes which they determine? Is a law proposed concerning private debts? It is a question to which the creditors are parties on one side and the debtors on the other."

${ }^{36}$ See Richardson, 2003 pp. 119-127 for an application of this idea to administrative decision-making.
} 
It is thus perhaps more helpful to understand "the rule of law" not as the impartial application of general legal rules to particular circumstances - whether those legal rules are the separation of powers or some other statute - but of particular orientation in thinking. The rule of law might be considered as a way to vindicate the ideal of political equality by incorporating universality and reflexivity into public decision-making processes by historically situated, distinct individuals. Stated differently, we might exchange the static Rechstaadt of Kant for due process and the deliberative justice of Habermas; or the legal formalism of Dicey for the legal realism of Pound, Hale, and Dewey. If read as a mandate to design institutions that encourage equal participation and respect, the rule of law is, perhaps, another way of expressing democratic autonomy: to act as if were possible for moral equals to come to a consensus about the laws that bind them. ${ }^{37}$ This means, pace Vermuele's political theology (Emerson, 2019, pp. 14-15) that executive agencies should not go unconstrained by judicial review, Congressional oversight, and public accountability. It means, instead, that these checks and balances can be replaced, enhanced or otherwise modified in ways that permit citizens and their representatives to weigh in in a manner that respects their equal dignity. Indeed, administrative agencies, given their proximity to our dayto-day lives, can facilitate and rationalize the popular deliberation required to make equal dignity real for the rest of us. (Emerson, 2019, p. 66)

\section{Conclusion}

As the left flank of the Democratic Party spitballs ideas about a Green New Deal, the nationalization of healthcare, anti-monopoly and other business regulation, it is perhaps more urgent than ever to find legitimate ground for the public bodies that will inevitably be tasked to

\footnotetext{
${ }^{37}$ Felix Frankfurter, for example, eschewed Dicey's definition of "rule of law" for "substantive justice both to public and private interests." Ernst, 2014, p. 19.
} 
implement them. Vague instructions that urge the "democratization" of administration are insufficient. Instead, institutional design should remain sensitive to extant political structures and focus on democratic autonomy, or how agencies can help citizens understand themselves as coauthors of their laws. This may mean that some agencies should not, in fact, be democratized. This may mean that agencies receive input from select portions of the citizenry. A Consumer Financial Protection Bureau should not become overly responsive to financial institutions; a labor board should not allow itself to be captured by corporate leadership. By understanding the lessons of political theory's representative turn, it is instead possible to embed agencies within constitutional, democratic decision-making institutions in a manner that vindicates agencies' effectiveness and expertise while also ensuring that citizens enjoy an equal chance to shape their collective goals. 


\section{Works Cited}

Ackerman, B. (1998). We The People: Transformations. Cambridge: Belknap Press.

Anderson, E. (2011). Democracy, Public Policy, and Lay Assessments of Scientific Testimony. Episteme, 8(2), 144-164.

Arato, A. (2017, October 11). How We Got Here. Public Seminar.

Arendt, H. (1967). Truth and Politics. The New Yorker.

Beckel, M. (2011, June 1). Lobbying Push Targeting Federal Regulatory Agencies Continues in Wall Street Reform Fight. Center for Responsive Politics.

Benhabib, S. (2006). Democratic Iterations: The Local, the National, and the Global. In S. Benhabib, \& R. Post, Another Cosmopolitanism (pp. 45-74). Oxford University Press.

Blythe, M., \& Matthijs, M. (2018). When Is It Rational to Learn the Wrong Lessons?

Technocratic Authority, Social Learning, and Euro Fragility. Perspectives on Politics, 16(1), 110-126.

Bobbio, N. (1987). The Future of Democracy. (R. Bellamy, Ed.) Polity.

Bodin, J. (1576). Les six livres de la Republique. Paris: Jacques du Puys.

Brugue, Q., \& Gellego, R. (2003). A Democratic Public Administration? Public Management Review, 5(4), 425-447.

Caliendo, L., Mion, G., Opromolla, L., \& Rossi-Hansberg, E. (2015). Productivity and Organisation in Portuguese Firms. Discussion Paper 10993. Center for Economic Policy and Research .

Canovan, M. (2005). The People. New York: Polity.

Carillo, R. (2020, August 20). Our Money Where Our Mouth Is. Current Affairs.

Chappel, J. (2020, Spring). Nudging Towards Theocracy: Adrian Vermeule's War on Liberalism. Dissent.

Cohen, J. L. (2004). Regulating Intimacy: A New Legal Paradigm . Princeton: Princeton University Press.

Cohen, J. L. (2015). Freedom of Religion, Inc.: Whose Sovereignty? Netherlands Journal of Legal Philosophy, 44.

Cohen, J. L., \& Arato, A. (1994). Civil Society and Political Theory. The MIT Press.

Dahl, R. A. (1947). The Science of Public Administration: Three Problems. Public Adminisitration Review, 7(1), 1-11.

Dahl, R. A. (1985). A Preface to Economic Democracy. Cambridge: Polity Press.

Dahl, R. A. (1990). Social Reality and Free Markets. Dissent, 37, Dahl, R. (1990224-28.

Dryzek, J. S., \& Niemeyer, S. (2008). Discursive Representation. American Political Science Review, 102(481-93).

Dunn, J. (1990). The Economic Limits to Modern Politics. Cambridge: Cambridge University Press.

Eisner, M. A. (2011). The American Political Economy: Institutional Evolution of Market and State. Routledge.

Emerson, B. (2019). The Public's Law: Origins and Architecture of Progressive Democracy. Princeton: Princeton University Press.

Ernst, D. R. (2014). Tocqueville's Nightmare: The Administrative State Emerges in America, 1900-1940. Oxford University Press.

Fishkin, J., \& Forbath, W. E. (2014). THE ANTI-OLIGARCHY CONSTITUTION. Boston University Law Review, 94, 669-96.

Galbraith, J. (2017). American Capitalism. Routledge. 
Galston, W. A. (2002). Liberal Pluralism: The Implications of Value Pluralism for Political Theory and Practice. Cambridge University Press.

Garfield, A. E. (2014). The Contraception Mandate Debate: Achieving a Sensible Balance. Columbia Law Review Sidebar, 114, 1.

Guy, M. E. (2003). Ties that Bind: The Link between Public Administration and Political Science. Journal of Politics, 641-55.

Habermas, J. (1971). Technology and Science as "Ideology". In $n$ Toward a Rational Society: Student Protest, Science and Politics. Beacon Press.

Hayek, F. A. (1976). Law, Legislation \& Liberty Vol. 2. University of Chicago Press.

Hirschman, A. O. (1970). Exit, Voice and Loyalty: Responses to Decline in Firms, Organizations, and States. Harvard University Press.

Holmes, S. (1995). Passions and Constraint. Chicago: University of Chicago Press.

Holyoke, T. (2015). Theodore J. Lowi, The End of Liberalism: The Second Republic of the United States. In M. Lodge, E. Page, \& S. J. Balla, The Oxford Handbook of Classics in Public Policy and Administration. Oxford: Oxford University Press.

Jackson, T. (2020, April 16). The Sovereign Fed. Dissent.

Kalyvas, A. (2005). Popular Sovereignty, Democracy, and the Constituent Power. Constellations, 12(2), 223-244.

Kessler, J. K. (2016). The Political Economy of “Constitutional Political Economy”. Texas Law Review, 94, 1527-54.

Klooster, J. v. (Forthcoming 2020). The Ethics of Delegating Monetary Policy. Journal of Politics.

Lefort, C. (1986). The Political Forms of Modern Society Bureaucracy, Democracy, Totalitarianism. (J. P. Thompson, Ed.) MIT Press.

Lefort, C. (1988). Democracy and Political Theory. (D. Macey, Trans.) Minneapolis : University of Minnesota Press.

Lowi, T. J. (1969). The End of Liberalism. Norton.

Manin, B. (1997). The Principles of Representative Government. Cambridge: Cambridge University Press.

Metzger, G. E. (2013). Administrative Constitutionalism. Texas Law Review, 1897-1935.

Metzger, G. E. (2016). 1930s Redux: The Administrative State Under Siege. Harvard Law Review, 131(1), 2-95.

Michaels, J. D. (2017). Constitutional Coup: Privatization's Threat to the American Republic. Cambridge: Harvard University Press.

Mintrom, M. (2015). Herbert A. Simon, Administrative Behavior: A Study of Decision-Making Processes in Administrative Organization. In M. Lodge, E. C. Page, \& S. J. Balla, The Oxford Handbook of Classics in Public Policy and Administration. Oxford University Press.

Moore, A. (2017). Critical Elitism. Cambridge University Press.

Morgan, E. S. (1989). Inventing The People: The Rise of Popular Sovereignty in England and America (Rev'd ed.). New York: W. W. Norton \& Co.

Moyn, S. (2020, Winter). The Court is not your Friend. Dissent.

Moyn, S. (2020, August 24). The Guardians. The Nation.

Neuse, S. M. (1983). From Grass Roots to Citizen Participation: Where We've Been and Where We Are Now. Political Administration Quarterly, 7(4), 294-309. 
Novak, W. J. (2002). Legal Origins of the Modern American State. In A. Sarat, B. Garth, \& R. A. Kagan (Eds.), Looking Back at Law's Century (pp. 249-86). Ithaca: Cornell University Press.

Offner, A. C. (2019). Sort Out the Mixed Economy: The Rise and Fall of Welfare and Developmental States in the Americas. Princeton: Princeton University Press.

Oliver Wendell Holmes, J. (1894). Privilege, Malice, and Intent. Harvard Law Review, 8(1), 114.

Pistor, K. (2019). The Code of Capital. Princeton University Press.

Polanyi, K. (2001). The Great Transformation (2nd ed.). Beacon Press.

Posner, E., \& Vermuele, A. (2011). The Executive Unbound: After the Madisonian Republic. New York: Oxford University Press.

Pound, R. (1909). Liberty of Contract. Yale Law Journal, 454-87.

Rahman, K. S. (2016). Democracy Against Domination. New York: Oxford University Press.

Rahman, K. S. (2018). Reconstructing the Administrative State. Harvard Law Review, 131, 1671-1712.

Richardson, H. O. (2003). Democratic Autonomy. Oxford: Oxford University Press.

Rosanvallon, P. (2011). Democratic Legitimacy. (A. Goldhammer, Ed.) Princeton: Princeton University Press.

Schragger, R., \& Schwartzman, M. (2016). Some Realism about Corporate Rights. In M. Schwartzman, C. Flanders, \& Z. Robinson (Eds.), The Rise of Corporate Religious Liberty (pp. 345-72). Oxford University Press.

Shklar, J. N. (1986). Legalism: LAw, Morals, and Political Trials. Cambridge: Harvard University Press.

Skocpol, T. (1985). Bringing the State Back In: Strategies of Analysis in Current Research. In P. B. Evans, D. Rueschemeyer, \& T. Skocpol, Bringing the State Back In (pp. 3-38).

Smithburg, D. W. (1951). Political Theory and Public Administration. Journal of Politics, 13(1), 59-69.

Strauss, P. L. (2020). Eroding "Checks" on Presidential Authorty: Norms, the Civil Service, and the Courts . Chicago-Kent L. Rev., 581-91.

Streeck, W. (2017, March-April). The Return of the Repressed. New Left Review, 104, 5-18.

Tankus, N. (2020, May). The Federal Reserve's Coronavirus Crisis Actions, Explained: Riots, Municipalities and Monetary Policy. Notes on the Crisis.

Tooze, A. (2018). Tempestuous Seasons. New Left Review, 40(17), 19-21.

Tooze, A. (2020, May 13). The Death of the Central Bank Myth. Foreign Policy.

Tucker, P. (2018). Unelected Power: The Quest for Legitimacy in Central Banking and the Regulatory State. Princeton University Press.

Tully, J. (2002). The Unfreedom of the Moderns in Comparison to Their Ideals of Constitutional Democracy. Modern Law Review, 65(2), 204-28.

Turner, S. (2003). Liberal Democracy 3.0: Civil Society in the Age of Experts. SAGE.

Urbinati, N. (2014). Democracy Disfigured. Harvard University Press.

Urbinati, N., \& Warren, M. E. (2008). The Concept of Representation in Contemporary Democratic Theory. Annual Review of Political Science, 11, 387-412.

van't Klooser, J. (Forthcoming 2020). The Ethics of Delegating Monetary Policy. Journal of Politics.

Vermuele, A. (2016). Law's Abnegation. Harvard University Press. 
Verovsek, P. J. (2020, January 28). Public intellectuals and experts cannot tell citizens what to do. LSE Brexit .

Vile, M. (1967). Constitutionalism and the Separation of Powers. Liberty Fund.

Waldo, D. (2006). The Administrative State. Routledge.

Waldron, J. (1999). Law and Disagreement. Oxford: Clarendon Press.

Webber, G. C. (2009). The Negotiable Constitution: On the Limitation of Rights. Cambridge University Press.

Wilson, W. (1887). The Study of Administration. Political Science Quarterly, 2(2), 197-222.

Winkler, A. (2018). We the Corporations: How American Business Won Their Civil Rights. New York: Liveright Publishing Corp.

Zuboff, S. (2019). The Age of Surveillance Capitalism. Public Affairs. 